\title{
Yumuşak Gücün Yönetim ve Sağlık Yönetimi Açısından Değerlendirilmesi
}

\author{
Zekai ÖZTÜRK \\ Ankara Hacı Bayram Veli Üniversitesi, Sağlık Yönetimi \\ zekai.ozturk@hbv.edu.tr \\ ORCID: http://orcid.org/ 0000-0001-9930-7181. \\ Figen ÖZŞAHIN \\ Avrasya Üniversitesi, Diş Protez Teknolojileri \\ figen.ozsahin@avrasya.edu.tr \\ ORCID: http://orcid.org/0000-0001-9227-4938
}

Nazmiye EKİNCI

İzmir Kavram Meslek Yüksekokulu, Sağlık Kurumları İşletmeciliği nazmiye.ekinci@kavram.edu.tr

ORCID: http://orcid.org/0000-0002-7007-4123

\begin{tabular}{lrr} 
Derleme Makale & DOI: $10.31592 /$ aeusbed.726832 \\
\hline Geliş Tarihi: 26.04 .2020 & Revize Tarihi: 10.03 .2021 & Kabul Tarihi: 26.03.2021
\end{tabular}

\section{Atıf Bilgisi}

Öztürk, Z., Özşahin, F. ve Ekinci, N. (2021). Yumuşak gücün yönetim ve sağlık yönetimi açısından değerlendirilmesi. Ahi Evran Üniversitesi Sosyal Bilimler Enstitüsü Dergisi, 7(1), 360-374.

\section{ÖZ}

Yumuşak güç kavramı, çağdaş yönetim anlayışında güncel konular arasında değerlendirilmektedir. Yumuşak güç kavramını ilk kez Joseph S. Nye "Liderliğe Zorunluluk: Amerikan Gücünün Değişen Doğası" adlı eserde ortaya koymuştur. Yönetimde liderlik gücü adı altında tartışılan yumuşak güç, 1990'l1 yıllardan günümüze kadar birçok alanda kullanılan (özellikle de dış politikada) ve eleştirilen bir kavramdır. Bu çalışmanın amacı, güç, güç kaynakları, yumuşak güç ve alt boyutları hakkında bilgiler vermek; konu hakkında yapılan çalışmaları ortaya koymak ve sağlık yönetimi ve yönetim alanı açısından yumuşak güç kavramının değerlendirilmektir. Bu kapsamda, öncelikle konuya ilişkin detaylı kuramsal bilgiler sunulmuş ve sonrasında araştırma literatürü Web of Science'ta ve Ulusal Tez Merkezi'nde yer alan çalışmalara göre bibliyometrik analiz yöntemi ile oluşturulmuştur. Ardından da sağlık yönetimi ve yönetim alanı açısından yumuşak güç kavramı değerlendirilmiştir. Çalışmanın sonucunda yöneticilerin ve sağlık yöneticilerinin diğer bireylerle ve kurumlarla iletişim kurdukları tüm süreçlerde yumuşak gücü kullanmalarının önem taşıdığı görülmüştür. Ayrıca alanyazında sağlık alanında yumuşak güç kavramına ilişkin çalışmaların az sayıda olduğu ve bu konuda yapılacak yeni çalışmalara ihtiyaç duyulduğu belirlenmiştir. Bu çalışma ayrıca konu hakkında yapılacak olan yeni çalışmalara yol göstermesi açısından önem taşımaktadır.

Anahtar Kelimeler: Güç, liderlik gücü, güç kaynakları, yumuşak güç, sağlık yönetimi.

\section{Evaluation of Soft Power in Terms of Management and Health Management}

\begin{abstract}
The concept of soft power is considered among the current issues in contemporary management approach. The concept of soft power was first stated by Joseph S. Nye in his book "Bound to Lead: The Changing Nature of American Power." Soft power, which is discussed under the name of leadership force in management, is a concept used in many fields (especially in foreign policy) from the 1990s until today and it is a criticized concept. The purpose of this study is to give information about power, power supplies, soft power and its sub-dimensions; to reveal studies on the subject and to evaluate the concept of soft power in terms of health management and management. In this context, firstly, detailed information about the subject was presented and then there search literature was created according to bibliometric analysis and in the Web of Science and National Thesis Center. Then, the concept of soft power was evaluated in terms of health management and management area. As a result of the study, it has been observed that managers and health managers use soft power in all processes in which they communicate with other individuals and institutions. In addition, it has been determined in the literature that studies on the concept of soft power in the field of health are missing and new studies are needed on this subject. This study is also important in terms of guiding new studies on the subject.
\end{abstract}

Keywords: Power, leadership power, power supplies, soft power, health management. 


\section{Giriş}

Yumuşak güç kavramını açıklamadan önce yönetim alanında güç, otorite, liderlik gücü ve güç kaynakları gibi kavramlarının açıklanmasında yarar görülmektedir. Aşağıda güç, otorite, liderlik gücü ve güç kavramları detaylı bir şekilde açıklanmıştır:

Sosyal bilimlerde "güç" kavramı, başkalarını etkileyebilme yeteneği olarak ifade edilmektedir (Ertürk, 2013, s. 80). Yönetimde "otorite" kavramı ise kişiye görev aldığ kurum tarafindan verilen karar verme ve başkalarının(astlarının) davranışlarını belirleme ve yaptırım uygulama hakkıdır. $\mathrm{Bu}$ hak, o kişiye, o mevkiiyi işgal ettiği için verilmiştir (Koçel, 2018, s. 571).

İnsanlar bazen gücü, sonuçları etkileyebilecek kaynaklara sahip olmak şeklinde tanımlarlar. $\mathrm{Bu}$ durumda bir kişi veya grup, eğer büyük, istikrarlı ve zenginse güçlü olarak görülür, ancak bu yanlıştır. Bazı analistler bu duruma "araç yanlışlı̆̆ı" veya "somut yanlışlık" ifadesini kullanmayı uygun görmektedir. Gücü, onu üreten kaynaklarla eşanlamlı olarak tanımlayan insanlar, güç kaynaklarına en iyi şekilde sahip olanların her zaman istedikleri davranışsal sonuçları alamadıkları paradoksuyla karşılaşırlar. Örneğin, Amerika Birleşik Devletleri (ABD), Vietnam Savaşı'nı kendisinden daha güçsüz ancak daha kararlı bir rakibe karşı kaybetmiştir. Bu duruma bir başka örnek verilirse en iyi kartları elinde tutan bir oyuncu, bazen oyunu kaybedebilmektedir (Nye, 2008, s. 28).

Yumuşak güç, bir hususun yapılması konusunda emretmeye gerek duyulmadan başkalarının kendi istediklerimizi istemelerini sağlayan bir güç türüdür ve emretmeyi gerektirmeden bir işi yaptırmayı sağladığı için oldukça önemlidir. Alanyazında yönetim ve sağlık (sağlık yönetimi) alanlarında yumuşak güç kavramına ilişkin çok az miktarda çalışma yer almaktadır. Yumuşak güç kavramına ilişkin ilgili literatür taranırsa, çalışmaların genellikle yönetim ve/veya sağlık yönetimi dışındaki alanlarda ele alındığı (örneğin, siyasal bilimler ve uluslararası ilişkiler alanlarında) görülecektir. Dolayısıyla çalışmanın problem cümlesini "yönetim ve sağlık (sağlık yönetimi) alanlarında yumuşak güç kavramı nasıl ele alınmalıdır" oluşturmaktadır.

$\mathrm{Bu}$ çalışmanın amacı, güç, güç kaynakları, yumuşak güç ve alt boyutları hakkında bilgiler vermek; konu hakkında yapılan çalışmaları ortaya koymak ve sağlık yönetimi ve yönetim alanı açısından yumuşak güç kavramının değerlendirilmektir. Bu kapsamda, öncelikle konuya ilişkin detaylı kuramsal bilgiler sunulmuş ve sonrasında araştırma literatürü Web of Science'ta ve Ulusal Tez Merkezi'nde yer alan çalışmalara göre bibliyometrik analiz yöntemi ile oluşturulmuştur. Ardından da sağlık yönetimi ve yönetim alanı açısından yumuşak güç kavramı değerlendirilmiştir.

Aşağıda konuya ilişkin detaylı bilgiler bulunmaktadır:

\section{Güç Alanı, Güç Taktikleri ve Gücün Kaynakları}

Güç kavramının iyi anlaşılabilmesi için bunu bütünleyen güç alanı, güç taktikleri ve güç kaynaklarını kısaca anlatmakta fayda vardır. Güç konusu, güç sahibinin başkalarını hangi konularda etkilediğini gösterir. Güç alanı, güç sahibi olan kişinin etkileyebildiği toplam kişi sayısını ifade eder (Şimşek, 1999, s. 168).

Literatür incelendiğinde çalışanların yöneticilerini, iş arkadaşlarını veya yöneticilerin çalışanlarını etkilemek için dokuz ayrı güç taktiğini kullandığı görülmüştür. Bunlar (Judge ve Robbins, 2017, s. 466-467):

-Meşruluk; kişinin otorite pozisyonuna güvenerek örgütsel politikalar veya kurallar ile anlaşmayı talep etmesidir.

- Rasyonel ikna; bir isteği göstermek için mantıksal argümanlar ve somut kanıtlar sunmaktır.

-İlham verme; çalışanların değerlerine, gereksinimlerine, umutlarına ve özlemlerine hitap ederek duygusal bağl1lik geliştirmektir. 
-Danışma; planları nasıl gerçekleştireceğine karar verirken çalışanları da dâhil ederek desteğin artırilmasidir.

-Değiş tokuş; bir isteğin yerine getirilmesi karşılığında çalışanların ödüllendirilmesidir.

-Kişisel istek; ilişkilerin arkadaşlık ve dostluk temeline dayanmasını istemektir.

-Göze girmek; bir istek de bulunmadan önce övgüde bulunmak ve dostça davranışlar göstermektir.

-Baskı yapma; çalışanlara karşı uyarılarda, tekrarlanan taleplerde ve tehditlerde bulunmaktır.

-Koalisyon; çalışanları katılmaya ikna etmek için başkalarının yardımını veya desteğini almaktır.

Yukarıdaki açıklamalarda, insanların güç taktiklerini kullanmak için birçok farklı yolu tercih edebilecekleri görülmektedir. Liderlik etmek için güce sahip olmak gerekmektedir. Bununla birlikte, gücü ölçmek zordur. Bir ilişkide daha fazla güce sahip olanlar, değişim yapmak ve direnmek için daha iyi bir konumdadırlar. Ampirik çalışmalar da bu durumu desteklemektedir (Nye, 2008, s. 29).

Güç kaynakları ise; kişinin başkalarını etkileyebilmek için hangi kaynaklardan yararlandığını ve kişinin gücünü nereden aldığını açıklar (Şimşek, 1999, s. 168). Güç kaynakları arasında zorlayıcı güç, ödüllendirme gücü, yasal güç, karizmatik güç, uzmanlık gücü yer almaktadır. Bu güç kaynakları aşağıda detaylı bir şekilde açıklanmıştır:

Zorlayıcı gücün temeli çalışanların olumsuz sonuçlardan korkmasına dayanmaktadır. Fiziksel düzeyde zorlayıcı güç, acı verme, hareketin kısıtlanması veya temel fizyolojik ya da güvenlik gereksinimlerinin engellenmesi nedeniyle tehdide dayanır. Örgütsel düzeyde ise, B (çalışan) kişisinin işini yaptığı halde A (güç sahibi) kişisi onu işten çıkarabiliyorsa veya rütbesini düşürebiliyorsa, A kişisi B kişisinin üzerinde zorlayıcı bir güce sahiptir. Eğer A kişisi B kişisini, onu rahatsız edici bulduğu çalışma aktivitelerine atayabiliyorsa A kişisi zorlayıcı gücü kullanmış olmaktadır. Diğer bir bakış açısıyla zorlayıcı güç, önemli bilgilerin saklanmasından da kaynaklanabilir. Bir kuruluşta başkalarının ihtiyaç duyduğu veri ve bilgiye sahip kişiler başkalarını onlara bağımlı yapabilir (Judge ve Robbins, 2017, s. 462).

Zorlayıcı gücün zıddı ise ödüllendirme gücüdür (Judge ve Robbins, 2017, s. 462). Bir başka deyişle, astlar üstlerinin istekleri doğrultusunda davrandıklarında ödüllendirilecekleri algısına sahip olurlar (Çalışkur, 2015). Bu ödüller, zamlar veya primler gibi finansal şekilde olabileceği gibi: ödüller görevde yükselme, takdir görme gibi finansal olmayabilir (Judge ve Robbins, 2017, s. 462). Finansal olmayan ödüller, bazen daha motive edici olarak görülebilir (Ward, 2001, s. 145). Aslında bu güç yöneticinin ödül ve kaynaklar üzerindeki denetiminden kaynaklanmaktır. Yöneticinin yaptığı denetim çalışanı fiziksel olarak olmasa da psikolojik açıdan etkileyebilir (Bayrak, 2001, s. 8).

Yasal güç, grup üyelerinin, üstlerin astların davranışlarını belirleme hakkına sahip olduğunu kabul etmesiyle alakalıdır (Şimşek, 1999, s.168). Yasal güç sahibi kişiler belirli bir yasa veya talimatın içeriğine katılamayacak olsalar bile astlardan itaat bekleme haklarına sahiptirler ve astların buna uyma zorunluluğu vardır (Beetham, 1991, s. 29). Astların kendilerini zorunlu hissetmelerinin birçok nedeni olabilir. Toplumun kültürel değerleri, belirli bir örgüte veya gruba katılma isteği ve bu istek sonucunda o grup veya örgütün değerlerini ve kurallarını kabul etmek bunu etkileyebilir. Bu sebeplerden astlar üstlerden gelen emirleri yerine getirecekler veya yerine getirmek zorunda olduğunu düşünecektir (Koçel, 2018, ss. 572-573).

Karizmatik güç, yöneticinin sahip olduğu kişilik özellikleri ile kendisini takip edenleri etkilemesine denir (Bakan ve Büyükbeşe, 2010, s. 4). Karizmatik güç, bir başkasının takdirinden ve o kişi gibi olma arzusundan gelişir. Örneğin, ünlülere reklamlarda ürünleri desteklemek için neden milyonlarca dolar ödendiğini açıklamaya yardımcı olur. Resmi liderlik pozisyonlarında olmayan bazı insanlar, karizmatik dinamizmleri, benzerlikleri ve duygusal çekicilikleri nedeniyle, karizmatik gücü vardır ve diğerleri üzerinde etkisi vardır (Judge ve Robbins, 2017, s. 466). House'a (1992) göre karizmatik güce sahip olan kişinin üç temel özelliği vardır. Bunlar, yüksek bir özgüvene sahip olma, 
yüksek bir etkileme yeteneği ve kendi inançlarının ahlaki yönden doğru olduğuna güçlü bir şekilde ikna etme becerisi olarak belirtilmiştir (House, 1992, s. 6).

Uzmanlık gücü, üst düzey yöneticilerin çevresel durumlarla başa çıkabilme ve örgütün başarısına katkıda bulunmak adına kullandığı bir güç kaynağıdır (Finkelstein, 1992, s. 509). Koçel'e (2018, s. 573) göre uzmanlık gücü lider veya yöneticinin sahip olduğu tecrübe ve bilgi ile ilgilidir. Burada karizmatik güçte olduğu gibi uzmanlık gücünde de astların üstleri hakkındaki algısı da önemlidir. Astlar üstlerinin tecrübesine ve bilgisine ne kadar çok güvenirse yöneticinin astlarını etkilemesi ve dinlemesi o derece daha kolay olacaktır (Şimşek, 1999, s. 169). Organizasyonlar daha karmaşık hale geldikçe yönetim daha fazla uzmanlık gerektirmekte ve uzmanların gücü giderek daha artmaktadır. Özellikle bilginin hâkim olduğu örgütlerde aralarında hiyerarşi olmasına rağmen uzmanlar da üstleri kadar söz sahibi olabilmektedir (Bayrak, 2001, s. 5). Örneğin: bilgisayar uzmanlar1, muhasebeciler, ekonomistler, endüstriyel psikologlar ve diğer uzmanlar uzmanlıklarının bir sonucu olarak güç kullanırlar (Judge ve Robbins, 2017, s. 463).

\section{Yumuşak Güç Kavramı}

Alanyazında "yumuşak güç" kavramı ilk kez Harvard Üniversitesi'nden Joseph Nye tarafından 1990'ların başında ortaya atılmış ve zaman içerisinde bu kavram etrafında geniş bir literatür oluşmuştur. Yumuşak güç, en yalın anlamıyla bir ülkenin diğer ülkelerden istediklerini askeri güç ve ekonomik zorlamalar yerine, onları sosyal ve kültürel unsurlarıyla cezbederek alabilme kabiliyetini ifade etmektedir. Yumuşak gücü kullanmanın çok değişik ve inovasyona açık yolları bulunmaktadır (Gür, 2014, s. 2).

Güç, istediğiniz sonuçları elde etmek için başkalarını etkileme yeteneğidir. Bir insan diğer insanların davranışlarını üç şekilde etkileyebilir. Bunlar; zorla ve tehditlerle, teşvik ve ödemelerle ya da başkalarının istediği şekilde dikkat çeken çekicilikle etkileyebilirler (Nye, 2008, s. 94).

Yumuşak güç, zorlamalardan ziyade cazibe yoluyla istediğinizi elde etme yeteneğidir. Başkalarının istediklerini kendi istediğimiz tarafa doğru çekmeye ikna edersek zorluk kullanmaya gerek kalmaz. Zorlama yeteneği, bir ülkenin askeri ve ekonomik gücünden doğar. Yumuşak güç, bir ülkenin kültürünün, politik ideallerinin ve politikalarının çekiciliğinden kaynaklanmaktadır. Politikalar başkalarının gözünde meşru olarak görülüyorsa, sahip olunan yumuşak güç artar (Nye, 2004, s. 2).

Sert güç; bir devletin ekonomik ve askeri olanaklarını yaptırım aracı olarak kullanarak başka devlet veye devletlerin davranışları üzerinde kendi lehine değişiklik yapabilme veya nüfuz sağlayabilme becerisine karşıllı gelmektedir (Battır, 2019, s. 152). Yumuşak güç, bir anlamda sert gücün tam zıddıdır. Yumuşak güç sert gücün, koşullarını değiştirerek başkalarının davranışlarını etkileme yeteneği olduğu anlamına gelir (Vuving, 2009, s. 6). Akıllı yöneticiler, liderliğin yalnızca komut verme meselesi olmadığını, aynı zamanda örnek olarak liderlik etmeyi ve başkalarının yapmalarını istediğiniz şeyi yapmak için çekmeyi de içerdiğini bilir. Bir işletme uzmanının yorumuyla, yöneticiler her şeyi kontrol edemez. Bunun yerine etki, ikna ve çok fazla eğitim yoluyla çalışmak zorundalardır. Kurum kültürü (insanların öğrendiği ortak örgütsel değerler) genellikle herhangi bir yöneticinin kuralları veya talimatları değil, insanları yönlendiren şeydir. Otoriter ülkelerdeki liderler zorlama ve sorun emirlerini kullanabilirken, demokrasilerdeki siyasetçiler teşvik ve çekiciliğin bir kombinasyonuna daha fazla güvenmek zorundadır. Yumuşak güç, günlük demokratik politikaların temelini oluşturur (Nye, 2008, s.30).

Tercihleri belirleme yeteneği, çekici bir kişilik, kültür, politik değerler gibi maddi olmayan varlıklar ve meşru veya ahlaki otoriteye sahip olan politikalar ile ilişkilendirilme eğilimindedir. Bireyler, yumuşak güç kullanmaları sayesinde karşılarındaki kişilerden (astlar vb.) kendi istedikleri şeyi yapmalarını istemelerini sağlayabilirler. Yumuşak güç, bir etki kaynağıdır, ancak sadece bir etki değildir. Çünkü etki, tehditlerin zor gücüne de dayanabilir. Yumuşak güç, ikna etmekten ya da insanları argümanla hareket ettirebilmekten daha fazlasıdır, bunun önemli bir parçasıdır. Aynı 
zamanda, cazip ve çekici bir yetenektir. Davranışsal anlamda, yumuşak güç çekici güçtür. Kaynaklar açısından, yumuşak güç kaynakları bu tür çekiciliği üreten varlıklardır (Nye, 2008, s. 95).

\section{Yumuşak Gücün Boyutları}

Yumuşak gücün boyutlarına Tablo 1'de yer verilmiştir. Bu boyutlar arasında vizyon ilkesi, iletişim, duygusal zeka kavramları yer almaktadır.

Tablo 1

Yumuşak Gücün Alt Boyutları

\begin{tabular}{ll}
\hline & Yumuşak Gü̧̧ \\
\hline Vizyon İlkesi & Takipçileri etkileme \\
& Etkililik (İdealler ve yetenekler dengesi) \\
\hline İletişim & İkna edici kelimeler, işaretler ve örnekler \\
& Yakın ve uzak takipçileri ikna etme \\
\hline Duygusal Zekâa & İlişkileri yönetebilme kabiliyeti ve karizma \\
& Duygusal öz farkındalık ve kontrol \\
\hline
\end{tabular}

Kaynak: (Bostanc1, 2018)

Yukarıda belirtilen yumuşak gücün alt boyutları aşağıda açıklanmıştır: Yumuşak gücün alt boyutlarından biri vizyon ilkesidir. Vizyon, liderlerin ortak hedefler yaratmalarına yardımcı olma yollarından biridir. Genellikle vizyonlar geleceğin bir resmini sunar ve değişimi teşvik eder, ancak bazı vizyonlar geçmiş veya statükoyu çekici olarak gösterebilir ve insanları değişime direnmeye teşvik edebilir. Bir vizyon olmadan, başkalarının değişmesine öncülük etmek zordur. Federal Express'in Chief Executive Officer'1 (CEO'su) Frederick Smith, "liderliğin temel görevinin bir kuruluşun vizyonunu ve değerlerini iletmek olduğunu" iddia etmektedir. Paul O'Neill Alcoa'nın CEO'su olduğunda, işyeri güvenliğini vizyonunun özü olarak seçmiştir (Nye, 2008, s. 89).

Yumuşak gücün alt boyutlarından biri de iletişimdir. İletişim, İngilizcede 'communication' olarak görülen bu kavram Latincede ise "communis" (ortak) ve "communicato" (ortaklaşma) kelimelerinin kökeninden ortaya çıkmıştır (Baltacı, 2016, s. 49). İletişim, kaynak, hedef, mesaj ve ileti olmak üzere dört ögeden oluşmaktadır. Ayrıca kodlama, kod açma ve geri bildirim olmak üzere de üç tane iletişim süreci vardır (Kaya, 2010, ss. 7-10). Kişiler arası iletişim: "bilgi, duygu, düşünce, tutum ve kanılarla, davranış biçimlerinin kaynak ile alıcı arasındaki bir iletişim yoluyla bir insandan (insanlardan) diğerine (diğerlerine) bazı kanallar aracılı̆̆ıyla ve bir değişim amacıyla aktarılması süreci"dir (Kaya, 2010, s. 5). Örgütsel iletişim ise: "bilginin iki veya daha fazla kişi tarafından değiştirildiği ve anlaşıldığı, genellikle davranışı motive eden veya etkileyen bir süreç" olarak tanımlanmıştır (Kelly, 2000, s. 92).

İletişimin kişisel amaçları ne olursa olsun, temeldeki amacı çevre üzerinde etkin olmak, başkalarında davranış, tutum geliștirmek ve değiștirmektir (Altıntaş ve Çamur, 2001, s. 2). İletişimin örgütsel amacı ise profesyonel ilişkiler kurmak, çatışmaları en aza indirmek ve iş birliğini teşvik etmektir. İyi bir örgütsel iletişim örgütün kurallarını, düzenlemelerini ve normlarını uygulamasına ve disiplini sürdürmesine yardımcı olmaktır (Gochhayat, Giri ve Suar, 2017, s. 4).

İyi bir lider, hem kelimeler, semboller hem de kişisel örneklerle etkili iletişim kurar. Winston Churchill, başarısını sık sık bu ustalığına bağlamıştır (Nye, 2006, s. 10). Eski Yunanlıların yeteneklerini geliştirmek için hitabet okulu olduğu bilinmektedir. İyi hitabet becerileri de yumuşak güç üretmeye yardımcı olmaktadır. Nye (2008, s. 72), Amerikalı politikacı ve devlet adamı Woodrow Wilson'un yetenekli bir öğrenci olmadığını ancak liderlik için gerekli olduğunu düşündüğünden kendisini hitabet açısından geliştirdiğini belirtmiştir. Ayrıca Nye $(2008$, s. 72), protestanlığın öncülerinden olan Martin Luther King'in, konuşulan kelimenin ritimleri bakımından zengin bir Afrikalı-Amerikalı kilise geleneğinde büyümekten faydalandığını belirtmiştir (Nye, 2008, s. 72). 
Birebir veya küçük gruplar halinde iletişim kurabilmek hitabetten daha önemli olabilir. Örgütsel beceriler -etkili bir iç takipçi çemberini çekme ve yönetme becerisi - hitabet eksiklikleri telafi edebilir ve etkin kamu söylemleri düşük örgütsel becerileri kısmen telafi edebilir. Büyük hitabet becerilere sahip olmayan liderler ayrıca semboller, eylemler ve örgütlenme ile de etkili bir şekilde iletişim kurabilirler (Nye, 2006, ss. 10-11).

Yumuşak gücün alt boyutlarından bir diğeri duygusal zekâdır. Duygusal zekâ, kişinin kendisinin ve başkalarının duygularını izleme, aralarında ayrımcılık yapma ve bu bilgileri kişinin düşünce ve eylemlerini yönlendirmek için kullanma becerisini içeren sosyal zekânın alt kümesidir (Mayer ve Salovey, 1990, s. 189). Duygusal zekâ seviyeleri genetik olarak sabit değildir ve erken çocukluk döneminde de gelişmez. Gençlik yıllarından sonra çok az değişen IQ'dan farklı olarak, duygusal zekâ büyük ölçüde öğrenilmiştir ve yaşam boyunca gelişmeye ve deneyimlerimizden ders almaya devam eder (Goleman, 1995, s. 2).

Salovey ve Mayer (1990, s. 190-200) duygusal zekâyı dört ayrı boyut olarak kavramlaştırmışlardır. Bunlar arasında: benlikteki duyguların değerlendirilmesi ve ifade edilmesi, başkalarının duygularının değerlendirilmesi, benlikteki duyguların düzenlenmesi ve performansı kolaylaştırmak için duygu kullanımı yer almaktadır. Benlikteki duyguların değerlendirilmesi ve ifade edilmesi, bireyin derin duygularını anlama yeteneği ve bu duyguları doğal olarak ifade edebilme becerisiyle ilgilidir. Bu alanda büyük yeteneği olan insanlar, çoğu insandan önce duygularını algılar ve kabul eder. Başkalarının duygularının değerlendirilmesi, insanların duygularını algılama ve anlama yetenekleriyle ilgilidir. Bu kabiliyeti yüksek olan insanlar, zihinlerini okumanın yanı sıra başkalarının duygularına ve hislerine karşı çok daha duyarlıdırlar. Benlikteki duyguların düzenlenmesi, insanların psikolojik sıkıntıdan daha hızlı bir iyileşme sağlayacak olan duygularını düzenleme yeteneği ile ilgilidir. Performansı kolaylaştırmak için duygu kullanımı, bireylerin yapıcı etkinliklere ve kişisel performansa yönlendirerek duygularını kullanma yetenekleriyle ilgilidir (Salovey ve Mayer, 1990, s. 190-200).

Duygusal zeka, liderin kişisel tutkularını kanalize etmesini ve başkalarını çekmesini sağlayan, ustalık, disiplin ve empati kapasitesidir (Nye, 2006, s. 10). Duyguların her zaman düşünmeyi engellediği görüşünün aksine duygusal zekâ, duyguları anlama ve düzenleme yeteneğinin genel düşünmeyi daha etkili hale getirebileceğini öne sürmektedir. İki ana bileşeni vardır. Bunlar: benliğin ustalığı ve başkalarına erişim. Duygusal zekâ kavramının adı, modern gibi görünse de, kavram yeni bir kavram değildir. 1920'lerde, psikolog E. L. Thorndike "duygusal zekâ" y1 insan ilişkilerinde akıllıca davranma yeteneği olarak tanımlamıştır. Pratik insanlar liderlikteki önemini her zaman anlamışlardır. Çoğu tarihçi, Roosevelt'in bir lider olarak başarısının nedeninin, analitik IQ'sundan daha çok duygusal zekâsından kaynaklandığına hemfikirdir (Nye, 2008, s. 69). İş dünyasında, "finansal sonuçları yönetmek, liderin kendi iç hayatını yönetmesiyle başlar, böylece doğru duygusal ve davranışsal zincir reaksiyonu gerçekleşir. Tepeden başlayan ruh halleri en hızlı hareket etme eğilimindedir çünkü herkes patronu izler." İnsanlar gibi primat grupları, dikkatlerini lider üzerinde yoğunlaştırır. Yakından izlenen CEO'lar ve başkanlar, farkında olsunlar olmasınlar her zaman sinyaller iletmektedir. Duygusal zekâ, bu tür sinyallerin farkındalığını ve kontrolünü içerir (Nye, 2006, s. 10).

\section{Yumuşak Gücün Birimleri}

Literatürde yumuşak gücün birimleri arasında merhamet, görkem ve güzellik yer almaktadır. Bunlar aşağıda detaylıca açıklanacaktır:

Yumuşak gücün birimlerinden biri olan merhamet kavram1, kendini insanlara karşı kibar veya cömert olunduğunda, iyilik yapıldığında, onlara yardım edildiğinde, destek olunduğunda; onları korumaya çalışıldığında, önem verildiğinde, insanların haklarına, çıkarlarına saygı gösterildiğinde, insanlara karşı tehdit edici olmayan veya uygunsuz olmayan davranışlarda bulunulduğunda vb. birçok şekilde gösterebilir (Vuving, 2009, s. 9). Merhametli olmanın güce nasıl dönüştürebileceği şöyle ifade edilebilir; merhamet insanlarda şükran ve sempati uyandırır. Yöneticiler çalışanlarına karşı barışçıl ve iyi niyetli yaklaşarak onlarla iş birliği ortamı yaratır. Merhamet paradoks gibidir. Eğer yöneticiler 
çalışanlarına karşı sert ve saldırgan olup, her zaman kendilerini savunurlarsa çalışanlar yöneticilere direnç gösterirler. Ancak yöneticiler çalışanlarına karşı iyi niyetli ve barışçıl bir tutum sergilerlerse çalışanlar da yöneticilerle daha çok iyi geçinebilirler. Bu durum karşılıklı olabileceği gibi olmayabilir de. Çalışan, yöneticinin direkt kendisine karşı davranışlarına da bakabilir, üçüncü bir kişiye karşı davranışlarını da izleyebilir ve ona göre yöneticiye nasıl davranacağına karar verebilir (Vuving, 2009, s. 9-10).

Yumuşak gücün birimlerinden biri olan görkem bir insanın veya bir örgütün başarılı olabilmesi ya da yetenekli olabilmesi kabiliyetidir. Başarılı olan kişiler diğer insanlar üzerinde etki bırakırlar, çünkü onlar ortaya çıkan problemlerin üstesinden rahat gelirler ve bu konuda oldukça yetenek sahibidirler. Bu göstergeler görkemin bir işaretidir. Yönetici ne kadar yetenekli olursa diğer insanlar ona karşı daha az direnç gösterirler. Görkem birçok şekilde yumuşak güç ile ilişkilendirilebilir. Parlaklık, çeşitli şekillerde yumuşak güce dönüşebilir. Bunun bir yolu, onu yenilmezlik ve kaçınılmazlık efsanesi yapmak için uğraşmaktır. Başka bir şekilde, görkem taklit etmeye yol açar. Yani, "işini başarıyla yapan kişilerin çalışmalarına benzer bir çalışma yapılıyorsa, başarılı bireylerin yazdıklarından kişinin öğrenmeye çalışacağını ve onların başarının veya yeteneklerinin temelinde olduğunu düşündüğü şeyleri kopyalayacağını', ifade eder (Vuving, 2009, s. 10-11).

Yumuşak gücün birimlerinden biri olan güzellik, dünya siyasetindeki güzellik fiziksel çekiciliğe değil, ortak idealler, değerler, sebepler veya vizyonlar ile insanları birbirine yakınlaştıran karşılıklı anlayış ile alakalıdır. Karşıt değerler ve nedenler, rejimlerin birbirlerini çirkin görmesi için sağlam bir ortam sağlar ve paylaşılan değerler ve nedenler, diğer rejimin güzel olduğu algısına doğru bir itici güç sağlar ve bu da güven, dostluk ve iş birliğini teşvik eder. Güzelliğin bu güçlü özelliğini yumuşak güce çeviren temel sistem ise şu şekilde açıklanabilir: yöneticinin güçlü inancı, etkileyiciliği, kurum aidiyetliği, kurum vizyonunu geliştirmeye yönelik çabası, personele vizyon, değer ve idealleri açısından ilham kaynağı olabilir. Çalışanlar yöneticilerin bu güzelliğini fark ettiklerinde yöneticinin dediklerini uygularlar, yöneticiye olan bağlllıkları artar ve yöneticiyi takip ederler. Çünkü yönetici kurumda kayda değer bir şekilde kurumun vizyonunu, değerlerini ve hedeflerini temsil etmektedir (Vuving, 2009, s. 12).

\section{Araştırma Literatürü}

Yumuşak güç kavramına ilişkin araştırma literatürünün ortaya konulması için Web of Science'ta ve Ulusal Tez Merkezi'nde yer alan çalışmalar incelenmiştir. Bu kapsamda alanyazında yumuşak güç kavramına ilişkin olarak yapılmış çalışmaların genellikle siyasal bilimler ve uluslararası ilişkiler alanlarında yapıldığ 1 söylenebilir. Tablo 2'de ve Şekil 1'de yumuşak güç kavramına ilişkin olarak yapılmış Web of Science'ta 1975-2020 yılları arasında yer alan çalışmalarla ilgili bilgilere yer verilmiştir:

Tablo 2

Web of Science'ta Yer Alan Yumuşak Gü̧̧ Kavramına İlişkin Çalışmaların Alanları

\begin{tabular}{lc}
\hline & Yumuşak Gü̧̧ \\
\hline Alan & Calı̧̧̧ Sayısl \\
\hline Siyasal Bilimler & 377 \\
Uluslararası İlişkiler & 321 \\
Disiplinlerarası Sosyal Bilimler & 285 \\
Alan Çalışmaları & 144 \\
Tarih & 67 \\
Ekonomi & 60 \\
Bölgesel araştırmalar & 53 \\
Yönetim & 47 \\
Turizm, Otelcilik & 40 \\
İsletme & 35 \\
İletișim & 32 \\
Eğitim ve Eğitim Araştırmaları & 29 \\
Din & 24 \\
\hline
\end{tabular}




\begin{tabular}{ll}
\hline Sosyoloji & 18 \\
Hukuk & 15 \\
Dil & 13 \\
Turizm Otelcilik & 12 \\
Kültürel & 10 \\
Kamu yönetimi & 8 \\
Să̆llk & 0 \\
Toplam & 1590 \\
\hline
\end{tabular}

Tablo 2'de görüleceği gibi, Web of Science'ta yer alan yumuşak güç ile ilgili çalışmaların çoğu siyasal bilimler ve uluslararası ilişkilerle alakalıdır. Mühendislik alanında kullanılan yumuşak güç kavramının taşıdığı anlamla bu çalışmada ele alınan yumuşak gücün birbirlerinden farklı olduğu söylenebilir. Tüm bu çalışmalar içerisinde yönetim alanında yapılmış çalışmaların miktarı ise (toplam 1590 çalışma arasında 47 çalışma) Web of Science'ta \% 2,95'tir. Ayrıca Tablo 2'de Web of Science'ta yapılmış çalışmalar içerisinde sağlık alanında yumuşak güç kavramına ilişkin bir çalışmanın yer almadığ görülmektedir.

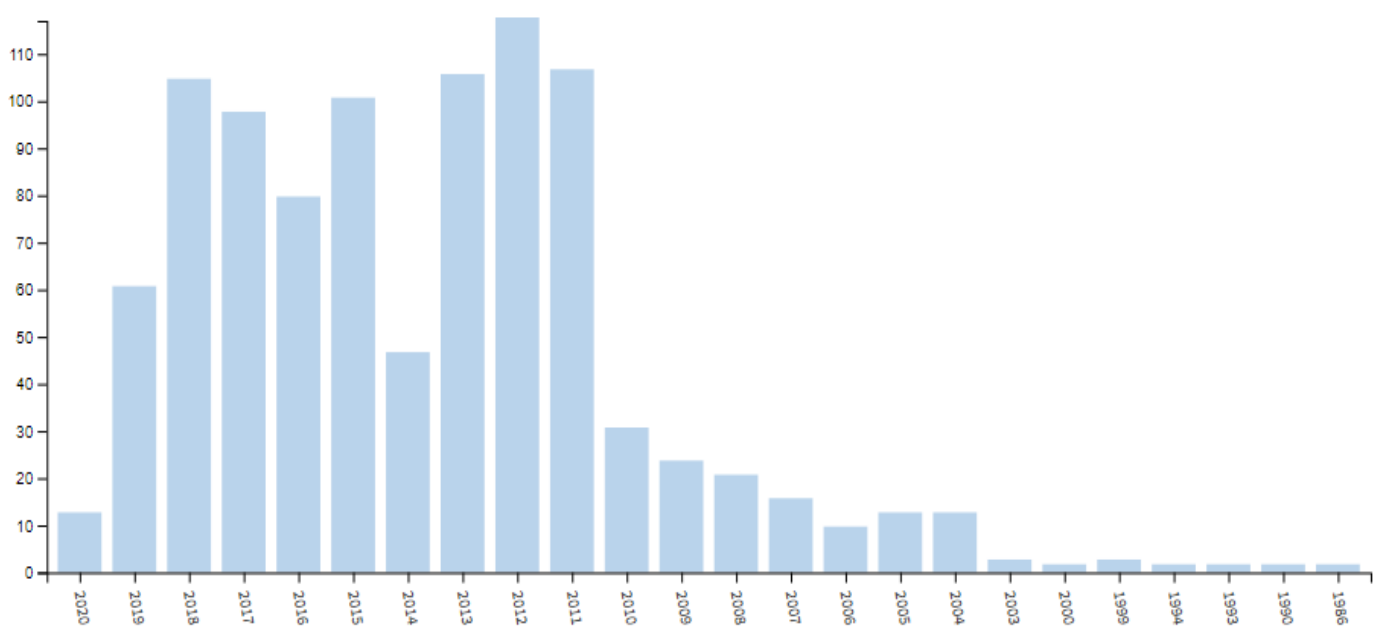

Grafik 1. Web Of Science’ta Yumuşak Güç Kavramına İlişkin Çalışmaların Yıllara Göre Dağılımı

Kaynak: (Web of Science, 2020)

Grafik 1'de yumuşak güç konusuna ilişkin çalışmaların daha çok 2011-2019 y1lları arasında yoğunlaştığ 1 görülmektedir.

Web of Science'ta yapılan analizle yumuşak güç kavramı için yapılan çalışmaların hangi ülke/bölgelerde yapıldığı da belirlenmiştir. Grafik 2'de konuya ilişkin çalışmaların yapıldığ 1 ülkelere ve bölgelere yer verilmiştir: 


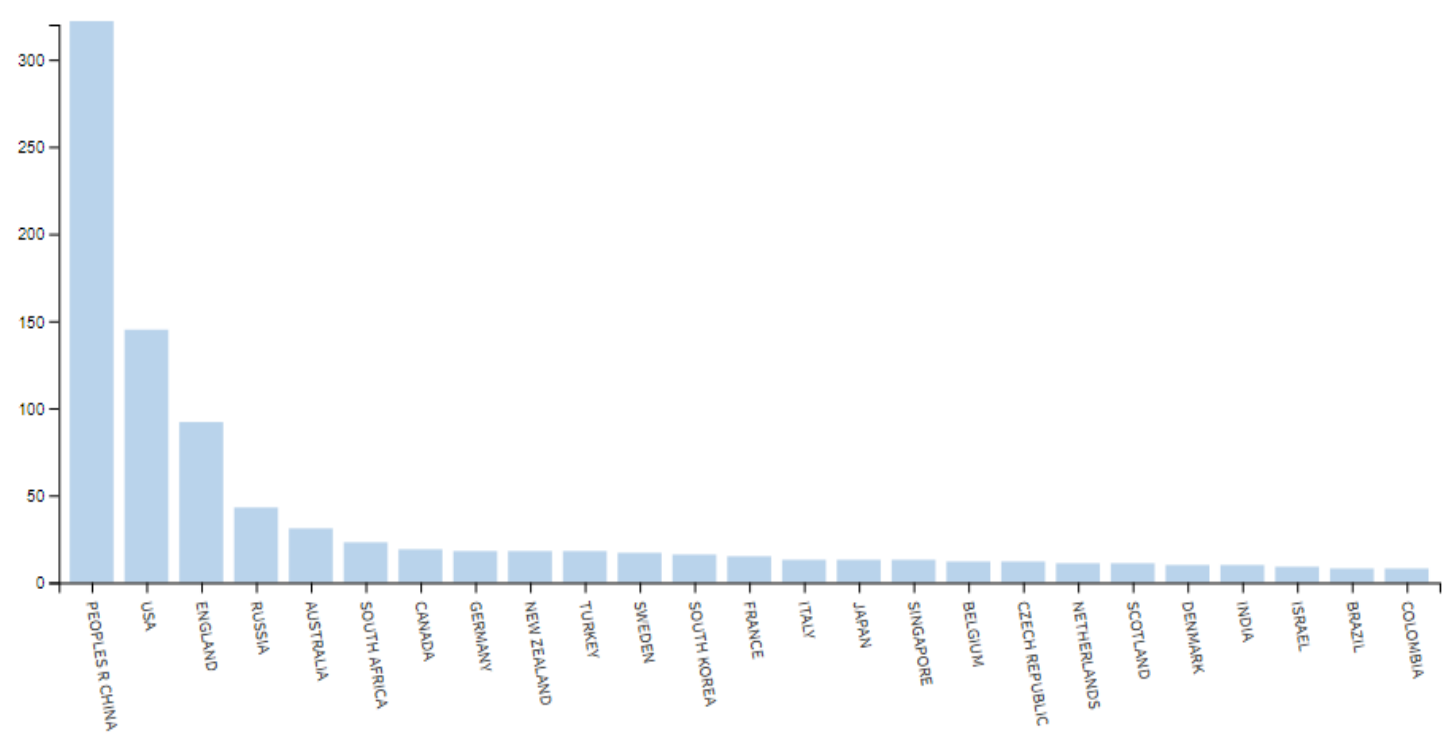

Grafik 2. Web Of Science’ta Yer Alan Yumuşak Güç Konusuna İlişkin Çalışmaların Yapıldığı Kaynak: (Web of Science, 2020) Ülkelere Göre Dağılımı

Grafik 2'de Web of Science'ya yapılan aramalarda yumuşak güç kavramına ilişkin çalışmaların sırasıyla en çok 320 çalışmayla Çin'de yapıldığı görülmektedir. Ayrıca ABD'de konuya ilişkin 143 çalışma ve İngiltere'de 90 çalışma yapıldığ belirlenmiştir. Türkiye'de yapılmış Web of Science'ta yer alan çalışma sayısı ise 16 'dır yani tüm çalışmaların \%1'idir.

Türkiye'de yumuşak güç kavramına ilişkin olarak yapılmış çalışmalar ise Ulusal Tez Merkezi'nde yer alan tezlere göre ifade edilmiştir. Tablo 3'te yer alan yumuşak güç kavramına ilişkin tezlere yer verilmiştir:

Tablo 3

Ulusal Tez Merkezi'nde Yer Alan Yumuşak Güç Kavramına İlişkin Tez Çalışmaları

\begin{tabular}{ll}
\hline & Yumuşak Gü̧̧ \\
\hline Alan & Çalş̧ma Sayısı \\
\hline Uluslararası İlişkiler & 60 \\
Siyasal Bilimler & 7 \\
Kamu Yönetimi & 7 \\
Eğitim ve Öğretim & 3 \\
Săgllk Yönetimi & 1 \\
Turizm & 1 \\
Mütercim-Tercümanlık & 1 \\
Din & 1 \\
Sivil havacılık & 1 \\
Halkla ilişkiler & 3 \\
Gazetecilik & 1 \\
İletişim bilimleri & 1 \\
Yönetim & 0 \\
\hline Toplam & 87 \\
\hline
\end{tabular}

Tablo 3'te yumuşak güç konusunu ele alan tez çalışmalarının uluslararası ilişkiler, siyasal bilimler, kamu yönetimi vb. alanlarında yapıldığı tespit edilmiştir. Sağlık Yönetimi alanında ise yumuşak güç konusunda 2018 yılında yapılan yalnızca bir çalışmanın (Bostancı, 2018) yer aldığı belirlenmiştir. Kısaca, alanyazında yönetim ve sağlık (sağlık yönetimi) alanlarında yumuşak güç kavramına ilişkin çok az miktarda çalışma yer almaktadır. 


\section{Yumuşak Gücün Yönetim ve Sağlık Yönetimi Açısından Değerlendirilmesi}

Yumuşak gücün uluslararası politikada ve dünya meselelerinde kullanımı iki büyük değişim geçirmiştir. Bilgi devrimi ve küreselleşmenin sonucu olan bu değişimler devletler arasında güç geçişi ve devletler arasındaki güç yayılımıdır (Nye, 2011, s.46). Güç kavramı, günümüzde ülkelerin yönetimi alanında da kullanılmaya başlanmıştır.

Yönetim, "başka insanlarla birlikte etkin ve etkili işler yapma sürecidir" (Robbinss ve Decenzo, 2001; Akt: Topaloğlu ve Koç, 2017, s. 31). Başka bir tanıma göre yönetim "başkalarının aracılığıyla amaca ulaşma ve başkalarına iş gördürme faaliyetidir” (Genç, 2013, s. 17-18). Yöneticiler, başkalarına iş yaptırırken çeşitli güç kaynaklarını kullanmak durumundadır. Bunlar arasında zorlayıcı güç, sert güç, ödüllendirme gücü vb. bulunmaktadır. Yumuşak güç de ülkelerin dış politikalarında kullanıldığı gibi yöneticilerin de kullandıkları bir güç kavramıdır. Yumuşak güç kavramı ülkelerin/bireylerin kendi istedikleri şeyleri diğer ülkelerin/bireylerin istemelerini sağlamalarıdır (Bostanc1, 2018, s. 46).

Yönetim açısından değerlendirildiğinde ise zeki yöneticilerin, önderliğin sadece tehdit etme ya da emir verme konusu olmadığını aynı zamanda, önderlik etmeyi ve çalışanlarının istediklerine önem vermeyi ve onları etkilemeyi de kapsadığını bilir. Büyük organizasyonlarda pek çok şey liderin denetim alanının dışındadır. Yöneticiler, diğer personellerinin de yöneticinin ve organizasyonun değerlerini ve vizyonunu kabullenmesini sağlayabilirse gücü daha da büyür (Bostancı, 2018, s. 46).

Yumuşak güç, ülkelerin/işletmelerin yönetiminde kullanılacağı gibi sağlı alanında yönetimde de sağlık yöneticileri tarafından kullanılabilmektedir. Kavuncubaşı ve Yıldırım (2012, s. 5) sağlık yönetimini, "sağlık alanında ortaya çıkan yönetim gereksiniminin karşılanmasına yönelik olarak gelişen, bu nedenle de tıp ve sağlı hizmetlerinin tüm boyutlarını işletmecilik perspektifiyle inceleyen, uzmanlaşmış yönetsel bir disiplin" şeklinde ifade etmişlerdir.

Sağlık hizmetleri ve sağlık kurumları kendine has birtakım özellikleri nedeniyle sağlık alanında yönetici olan kişiler tarafindan yumuşak gücün kullanımını gerektirmektedir. Sağlık alanında yapılan işlerin karmaşık ve değişken oluşu; sağlık hizmetlerinin 7 gün 24 saat kesintisiz olarak sunuluyor oluşu, hizmet miktarını belirleyen hekimlerin faaliyetleri üzerinde yönetsel ve kurumsal bir denetim mekanizmasının tam olarak bulunmaması; yapılan işlerin çoğunlukla acil ve ertelenemez oluşu ile yapılan işlerin hata ve belirsizliklere karşı oldukça duyarlı olması; sağlık kurumlarında ikili otorite hattının varlığı; sağlık çalışanların hemşire, doktor, vb. genellikle uzmanlaşma seviyesinin yüksek olduğu birbirinden farklı meslek mensuplarından oluşuyor olması ile sağlık kurumlarında çalışanlar arasında ya da sağlık kurumlarından sağlık hizmeti almaya gelen kişilerle sağlık çalışanları arasında zaman zaman çatışmaların yaşanıyor oluşu ve teşhis, tedavi edici, koruyucu, rehabilite edici ana sağlık hizmetlerinin yanında verilen birtakım hizmetler(otelcilik hizmetleri, yemekhane hizmetleri güvenlik hizmetleri vb.) için dış kaynaklardan yaralanma yoluna gidilmesi gibi birçok sebep sağlık yöneticilerinin yumuşak güç kullanımını gerekli kılmaktadır. Bostancı'nın (2018) Ankara'da Gazi Üniversitesinde sağlık yönetimi alanında yaptığı doktora tez çalışmasında, sağlık kurumlarında yöneticilik yapan bireylerin yumuşak güç kullanım yeterliliği algılamalarına sahip oldukları sonucuna ulaşmıştır.

\section{Sonuç ve Öneriler}

Profesyonel yöneticileri ve/veya sağlık yöneticileri, yönetim sürecinde zorlayıcı gücü, karizmatik güçlerini, uzmanlık güçlerini, cezalandırıcı güçlerini ya da liderlik güçlerini kullanabilmektedir. Bu güçlerin yanı sıra sağlık kurumlarını yönetenlerin yönetim süreçlerinde kullanabilecekleri araçlardan birisi de yumuşak güçtür.

Yukarıda açıklandığı gibi yumuşak güç kavramının literatürde birbirinden farklı birçok tanımı bulunmaktadır. Yukarıda açıklananlar ışığında yumuşak güç kavramının liderliğin güç kaynaklarından birisi olduğu ifade edilebilir. Merhamet, görkem, güzellik, zor kullanmama, tehdit etmeme, ikna etme 
gücünü kullanmayı ifade eden; yöneticilerin kişiliklerini, içinde bulundukları kültürel ve politik değerler vb. birçok unsuru içerisinde bulunduran bir kavramdır.

Sağlık kurumları işlevsel (fonksiyonel) bağımlılıkları çok yüksek olan kurumlar arasında yer aldığından ve matriks yapıda olduklarından bu kuruluşlarda sağlık çalışanları ile hasta ve hasta yakınları, yöneticiler, hastane tedarikçileri, Sosyal Güvenlik Kurumu, Sağlık Bakanlığı vb. ile ilişkilerin iyi tutulması oldukça önem taşımaktadır. Dolayısıyla hem yöneticilerin hem de sağlık yöneticilerinin tüm bu ilişkilerde (süreçlerde) yumuşak gücü kullanmalarının önemli olduğu düşünülmektedir. Özellikle hastalar ve hasta yakınları ile sağlı çalışanlarıyla olan iletişimde ve onları ikna etmede yumuşak gücün kullanılmasının olumlu sonuçlar vereceği düşünülmektedir.

Yumuşak gücün kullanımı için yöneticilere (ve/veya sağlık kurumları yöneticilerine) yardımcı olan unsurlar aşağıdaki gibi ifade edilebilir:

-Etkili iletişim kurabilmeleri

- İyi bir hitabet becerisine sahip olmaları

-Yönettikleri sağlık kurumlardaki insanları (kendilerini izleyenleri) etkili şekilde kendilerine çekebilmeleri,

•Sahip oldukları yönetme becerileri.

Sonuç olarak yumuşak güç kavramının dünyada genellikle siyasal bilimler ve uluslararası ilişkiler alanında daha çok kullanıldığı görülmüştür. Türkiye'de ise yumuşak güç kavramının genellikle uluslararası ilişkiler, siyasal bilimler, kamu yönetimi vb. alanlarında incelendiği tespit edilmiştir. Alanyazında sağlık alanında yumuşak güç kavramına ilişkin çok az sayıda çalışmanın yer aldığ 1 belirlenmiştir. $\mathrm{Bu}$ doğrultuda, sağlık yönetimi alanında yumuşak güç kavramına ilişkin çalışmalara ihtiyaç olduğu tespit edilmiştir. $\mathrm{Bu}$ çalışma, konu hakkında yapılacak olan yeni araştırmalara yol göstermesi açısından da önem arz etmektedir.

\section{Yazarların Katkı Oranı}

Bu makalede birinci yazarın \%40, ikinci yazarın \%30, üçüncü yazarın $\% 30$ oranında katkısı vardir.

\section{Çıkar Çatışması}

Bu çalışmada çıkar çatışması oluşturacak bir husus yoktur.

\section{Kaynaklar}

Bakan, İ. ve Büyükbeşe, T. (2010). Liderlik türleri ve güç kaynaklarına ilişkin mevcut-gelecek durum karşılaştırması. Karamanoğlu Mehmetbey Üniversitesi Sosyal ve Ekonomik Araş̧tırmalar Dergisi, 2, 73-84.

Baltacı, H. Ö. (2016). Illetişim becerileri ve empatik eğilim arasındaki ilişkinin X ve Y kuşaklarına göre farklılıklarının incelenmesi ve bir uygulama. Yüksek Lisans Tezi. Bahçeşehir Üniversitesi Sosyal Bilimler Enstitüsü, İstanbul.

Battır, O. (2019). Küreselleşme Çağında Bir Yumuşak Güç Unsuru Olarak Sağlık Diplomasisi. Anemon Muş Alparslan Üniversitesi Sosyal Bilimler Dergisi, 7(5), 151-161.

Bayrak, S. (2001). Yönetimde bir ihmal konusu olarak güç ve güç yönetimi-II. Süleyman Demirel Üniversitesi İktisadi ve İdari Bilimler Fakültesi Dergisi, 6(1), 23-42.

Beetham, D. (1991). The legitimation of power. Atlantic highlands. NJ: Humanuties Fress International. New York: Palgrave Publisher. 
Bostanc1, H. (2018). Sağlık kurumları yöneticilerinin yumuşak güç kullanım yeterliliklerinin ölçülmesi: Ankara ili örneği. Doktora Tezi. Gazi Üniversitesi Sosyal Bilimler Enstitüsü, Ankara.

Çalışkur, A. (2015). Yöneticinin güç kaynağı ile çalışanların örgüte duyduğu güven arasındaki ilişki. Dumlupınar Üniversitesi Sosyal Bilimler Dergisi, 45, 160-174.

Ertürk, M. (2013). Meslek yüksekokulları için yönetim ve organizasyon. İstanbul: Beta Yayınc1lı.

Finkelstein, S. (1992). Power in top management teams: Dimensions, measurement and validation. Academy of Management Journal, 35(3), 505-538.

Judge, T. A. and Robbins, S. P. (2017). Essentials of organizational behavior. Edinburgh: Pearson Education. 466-467.

Genç, N. (2013). Meslek yüksekokullart için yönetim ve organizasyon. Ankara: Seçkin Yayınc1lı.

Gochhayat, J., Giri, V. N. and Suar, D. (2017). Influence of organizational culture on organizational effectiveness: The mediating role of organizational communication. Global Business Review, 18(3), 691-702.

Goleman, D. (1995). Emotional intelligence. New York: Bantam Books.

Gür, N. (2014). Yeni Türkiye'nin yumuşak güç unsuru: Turizm. Seta Perspektif Dergisi, 58, 1-3.

House, R. J. (1992). Charismatic leadership in service-producing organizations. International Journal of Service Industry Management, 3(2), 5-16.

Nye, J. S. Jr. (Ekim, 2006). Soft Power, Hard Power and Leadership. 3, 9-13. https://numerons.files.wordpress.com/2012/04/soft-power-hard-power-andleadership.pdf adresinden 16 Mart 2020 tarihinde erişilmiştir.

Web of Science. (2020). Soft power. https://proxy.hacibayram.edu.tr:2309/RA/analyze.do?product=WOS\&SID=F1iu283aA5HqPL dLMhe\&field=PY_PublicationYear_PublicationYear_en\&yearSort=trueadresinden 12 Nisan 2020 tarihinde erişilmiştir.

Kavuncubaşı, Ş. ve Yıldırım, S. (2012). Hastane ve sağllk kurumları yönetimi. Ankara: Siyasal Kitabevi.

Kaya, A. (2017). Kişilerarası ilişkiler ve etkili iletişim. Ankara: Pegem.

Kelly, D. (2000). Using vision to improve organisational communication. Leadership \& Organization Development Journal, 21(2), 92-101.

Koçel, T. (2018). Işsletme yöneticiliği. İstanbul: Beta Yayıncıllk.

Nye, Jr. J. S. (2004). Soft power: The means to success in world politics. New York: Public affairs.

Nye, J. (2008). The powers to lead book. New York: Oxford University Press.

Nye Jr, J. S. (2008). Public diplomacy and soft power. The Annals of the American Academy of Political and Social Science, 616(1), 94-109. 
Nye, J. S. (2011). The future of power. New York: Public Affairs.

Salovey, P. and Mayer, J. D. (1990). Emotional intelligence. Imagination. Cognition and Personality, 9(3), 185-211.

Şimşek, Ş. (1999). Yönetim ve organizasyon. Ankara: Nobel Yayın Dağıtım.

Topaloğlu, M. ve Koç, H. (2017). Yönetim ve organizasyon kavramlar-teoriler- yaklaşımlar. Ankara: Seçkin Yayıncılık.

Vuving, A. (2009). How soft power works. Available at SSRN 1466220.

Ward, E. A. (2001). Social powerbases of managers: Emergence of a new factor. The Journal of Social Psychology, 141(1), 144-147. 


\section{Extended Abstract}

\section{Introduction}

Soft power: expressing compassion, glory (perfection), beauty, not using force, threatening, using persuasive power; the personalities of the managers, their cultural and political values et cetera (etc.) is a concept that includes many elements; is one of the power sources of leadership and one of the current issues in contemporary management. For the first time, the concept of soft power was introduced by Joseph S. Nye in his work "Necessity for Leadership: The Changing Nature of American Power". Soft power, which is discussed under the name of leadership force in management, is a concept that has been used and criticized in many fields, especially in foreign policy, from the 1990s until today.

The purpose of this study is to give information about power, power supplies, soft power and its sub-dimensions; To reveal the studies on the subject and evaluate the concept of soft power in terms of health management and management. In this context, firstly, detailed theoretical information about the subject was presented and then the research literature was created by bibliometric analysis method according to the studies in Web of Science and National Thesis Center (YOK Thesis). Then, the concept of soft power was evaluated in terms of health management and management area.

\section{Power, Power Field, Power Supply and Soft Power}

The subject of power shows which subjects the power owner affects others. The power field refers to the total number of people the power person can influence. Power sources, on the other hand, indicate which sources the person uses to influence others and where the person gets their power. Power sources include coercive power, rewarding power, legal power, charismatic power, expert power.

Soft power stems from the attractiveness of a country's culture, political ideals and policies. If policies are seen as legitimate in the eyes of others, the soft power possessed increases. Soft power is in a sense the opposite of hard power. Soft power means hard power has the ability to influence the behavior of others by changing its conditions.

Intelligent managers know that leadership is not just a matter of commanding, but also includes leading, for example, and pulling to do what you want others to do. With the comments of a business expert, managers cannot control everything. Instead, they have to work through influence, persuasion, and a lot of education. Corporate culture - common organizational values that people learn - is often what drives people, not the rules or instructions of any manager. While leaders in authoritarian countries can use coercion and problem orders, politicians in democracies have to rely more on a combination of encouragement and attractiveness. Soft power forms the basis of daily democratic policies.

Among the dimensions of soft power in the literature are the principles of vision, communication, emotional intelligence. In the literature, compassion, brightness and beauty are among the units of soft power.

\section{Conclusion and Evaluation}

Health institutions are among the institutions with very high functional (functional) dependencies and they have a matrix structure. In these organizations, healthcare professionals, patients and their relatives; managers; Keeping the relations with hospital suppliers, Social Security Institution, Ministry of Health and similar institutions very important is very important. Therefore, it is considered important that both managers and health managers use soft power in all these relationships (processes). It is thought that the use of soft power, especially in communication and persuading patients and their relatives, will yield positive results. 
Factors that help managers (and / or healthcare administrators) to use soft power include: being able to communicate effectively, having a good speaking skill, attracting people in the healthcare institutions they manage (effectively), and managing their own. In addition, it has been determined in the literature that there are few studies on the concept of soft power in the field of health and new studies are needed on this subject. This study is also important in terms of guiding new studies on the subject.

As a result, it was seen that the concept of soft power is generally used in the political sciences and international relations in the world. The concept of soft power in Turkey usually international relations, political science, public administration and so on. It has been determined that it is examined in the fields. It has been determined in the literature that very few studies on the concept of soft power in the field of health are included. On the occasion of, it has been determined that studies on the concept of soft power are needed in the field of health management. This study is also important in terms of guiding new research on the subject. 